\title{
Day Times Picogram Per Milliliter Per Milligram Per Gram Per Day
}

National Cancer Institute

\section{Source}

National Cancer Institute. Day Times Picogram Per Milliliter Per Milligram Per Gram Per

Day. NCl Thesaurus. Code C117909.

Day times picogram per milliliter, divided by milligram per gram per day. 